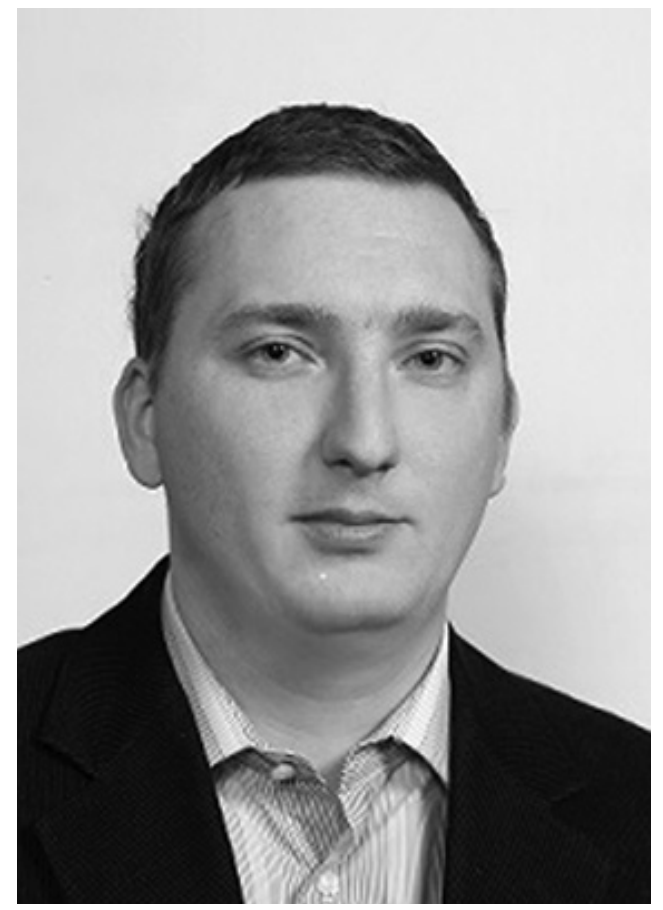

УДК: 330.341.1:159.9

DOI: https://doi.org/10.32689/2617-

2224-2020-1(21)-220-233

Омельяненко Віталій Анатолійович, кандидат економічних наук, доцент, Сумський державний педагогічний університет імені А. С. Макаренка, 40002, м. Суми, вул. Роменська, 87, тел.: +38 (095) 16759 52, e-mail: omvitaliy@ gmail.com

ORCID: 0000-0003-0713-1444

Омельяненко Виталий Анатольевич, кандидат экономических наук, дочент, дочент кафедрь бизнес-экономики и администрирования, Сумской государственный педагогический университет имени А. С. Макаренко, 40002, г. Сумь, ул. Роменская, 87, тел.: +38 (095) 16759 52, e-mail: omvitaliy@gmail.com

ORCID: 0000-0003-0713-1444

\title{
Omelyanenko Vitalii Anatoliyozych,
}

PhD, Associate Professor, Associate Professor of Business Economics and Administration Department, Sumy State Pedagogical University named after A. S. Makarenko, 40002, Sumy, Str. Romenska, 87, tel.: +38 (095) 16759 52, e-mail: omvitaliy@gmail.com

ORCID: 0000-0003-0713-1444

\section{АНАЛІЗ АРХЕТИПНОГО ВИМІРУ ІНСТИТУЦІЙНО-ЕВОЛЮЦІЙНИХ ТРАЕКТОРІЙ ВПРОВАДЖЕННЯ СИСТЕМНИХ ІННОВАЦІЙ}

Анотація. Історія сучасної України є періодом значних трансформацій усіх сфер суспільного життя. Тренди геополітики вимагають глибокої змістовної трансформації всіх сфер держави. А вона, в свою чергу, вимагає розробки відповідних стратегій з метою забезпечення конкурентоспроможності України та забезпечення суб’єктності. Це можливо реалізувати через підвищення якості управління державними ресурсами на основі системних рішень через інституційний підхід. Однак у практиці публічного управління України зазначені аспекти міждисциплінарного підходу до розуміння бази

\footnotetext{
${ }^{1}$ Робота виконувалася за рахунок бюджетних коштів МОН України, наданих на виконання науково-дослідного проекту № 0117U003855 “Інституційно-технологічне проектування інноваційних мереж для системного забезпечення національної безпеки України”.
} 
інституційних трансформацій практично не мають практичного втілення в рамках реформ, що призводить до втрати як їх інноваційного потенціалу, так і наявного соціального капіталу (психосоціальний потенціал за Е. Афоніним). Отже, маловивченими залишаються питання методології розробки цілеспрямованих змін інституціональної структури як детермінанти системної цілісності, вирішення проблеми оцінки взаємного впливу змін окремих інститутів та аналізу динаміки всієї інституціональної структури. Проаналізовано архетипні фактори функціонування макросистем, на які необхідно звернути особливу увагу для пошуку найбільш ефективних зусиль (ресурсів) в межах застосування концепції інституційно-еволюційних траєкторій впровадження системних інновацій. Розглянуто архетипну методологію до визначення основ формування інституційно-еволюційних траєкторій впровадження системних інновацій. Доведено, що фактори успішності реформ як системних інновацій пов'язані не тільки зі змінами структур та функцій інституціонального механізму держави, а насамперед з соціальними чинниками. Визначено, що фактором успішності системних інновацій є створення унікального середовища, що грунтується на поєднанні технологічно-інноваційного базису, економіки та соціально-культурної системи. Обгрунтовано, що для втілення ідей та потенціалу системних реформ в реальні інновації, тобто реалізації в соціально-економічному просторі країни, потрібен спектр об’єктивних і суб'єктивних причин, зокрема культурна “підтримка” інновацій відіграє досить важливу роль.

Ключові слова: системна інновація, архетип, інститут, стратегія, зміни, трансформації.

\section{АНАЛИЗ АРХЕТИПНОГО ИЗМЕРЕНИЯ ИНСТИТУЦИОННО-ЭВОЛЮЦИОННЫХ ТРАЕКТОРИЙ ВНЕДРЕНИЯ СИСТЕМНЫХ ИННОВАЦИЙ}

Аннотация. История современной Украины является периодом значительных трансформаций всех сфер общественной жизни. Тренды геополитики требуют глубокой содержательной трансформации всех сфер государства. А она, в свою очередь, требует разработки соответствующих стратегий с целью обеспечения конкурентоспособности Украины и обеспечение субъектности. Это возможно реализовать через повышение качества управления государственными ресурсами на основе системных решений с институционным подходом. Однако в практике публичного управления Украины указанные аспекты междисциплинарного подхода к пониманию базы институционных трансформаций практически не находит практического воплощения в рамках реформ, которое приводит к потере как их инновационного потенциала, так и имеющегося социального капитала (психосоциальный потенциал согласно Э. Афонину). Таким образом, малоизученными остаются вопросы методологии разработки целенаправленных изменений институциональной структуры как детерминанты системной целостности, решения проблемы оценки взаимного влияния изменений отдельных институтов и анализа ди- 
намики всей институциональной структуры. Проанализированы архетипные факторы функционирования макросистем, на которые нужно обращать особое внимание для поиска наиболее эффективных усилий (ресурсов) в рамках применения концепции институционно-эволюционных траекторий внедрения системных инноваций. Рассмотренна архетипная методология определения основ формирования институционно-эволюционных траекторий внедрения системных инноваций. Доказано, что факторы успешности реформ как системных инноваций связаны не только с изменениями структур и функций институционального механизма государства, а прежде всего с социальными факторами. Показано, что фактором успешности системных инноваций является создание уникальной среды, которая основана на объединении технологически-инновационного базиса, экономики и социально-культурной системы. Обосновано, что для внедрения идей и потенциала системных реформ в реальные инновации, то есть реализации в социально-экономическом пространстве страны, необходим спектр объективных и субъективных причин, в частности культурная “поддержка” инноваций играет довольно важную роль.

Ключевые слова: системная инновация, архетип, институт, стратегия, изменения, трансформации.

\section{ANALYSIS OF ARCHETYPIC DIMENSION OF INSTITUTIONAL-EVOLUTIONARY TRAJECTORIES OF SYSTEM INNOVATIONS}

Abstract. The history of the modern Ukraine is a period of significant transformation of all the spheres of the public life. Geopolitical trends require a profound meaningful transformation of all the spheres of the state. In turn, it requires the development of appropriate strategies in order to ensure Ukraine's competitiveness and ensure its subjectivity. This can be done by improving the quality of the public resource management through systemic decisions through an institutional approach. However, in the practice of public administration of Ukraine, these aspects of an interdisciplinary approach to understanding the base of institutional transformations find little practical implementation within the framework of reforms, which leads to the loss of both their innovative potential and existing social capital (psychosocial potential by E. Afonin). Thus, the methodology of developing purposeful changes in the institutional structure as determinants of systemic integrity, solving the problem of assessing the mutual impact of changes in individual institutions, and analyzing the dynamics of the entire institutional structure remain poorly understood. Therefore, the purpose of this study is to analyze the archetypal factors of the functioning of macro systems, which need to be paid particular attention in order to find the most effective points of effort (resources) within the framework of applying the concept of institutional and evolutionary trajectories of the systemic innovations. The archetypal methodology to determine the basics of the formation of institutional and evolutionary trajectories of implementation of systemic innovations is con- 
sidered in the research. The results of the study show that the success factors of reforms as system innovations are related not only to changes in the structures and functions of the institutional mechanism of the state, but above all to social factors. The study shows that the success of the systemic innovations is the creation of a unique environment of change based on a combination of technological and innovation basis, economy and socio-cultural system. It is substantiated that for the ideas and potential of the systemic reforms to turn into real innovations, that is, to be realized in the socio-economic space of the country, a whole range of objective and subjective reasons, in particular cultural "support" of innovation plays a rather important role.

Keywords: systemic innovations, archetype, institute, strategy, change, transformations.

Постановка проблеми. Історія сучасної України є періодом значних трансформацій усіх сфер суспільного життя. Якщо розвиток припускав збереження колишньої якості системи при здійсненні ряду внутрішніх змін на основі інновацій, то тренди геополітики вимагають глибокої змістовної трансформації всіх сфер. А вона в свою чергу вимагає розробки відповідних стратегій з метою забезпечення конкурентоздатності України та забезпечення суб'єктності. Це можливо реалізувати через підвищення якості управління державними ресурсами на основі системних рішень через інституційний підхід.

В сучасних умовах уряд, експертні кола, науковці пропонують численні проекти стратегічних системних реформ. Однак, як писав класик бізнес-літератури Пітер Друкер, “культура їсть стратегію на сніданок”. Стосовно відповідей на питання щодо якості цих проектів неможливо однозначно сказати, якщо не зрозуміло, у якій інституційній системі вони будуть працювати. То- му виникає питання оцінки цих проектів на відповідність культурному коду українців, для чого пропонуємо розглянути архетипний підхід та його сплив на динаміку інституційних змін.

Аналіз останніх досліджень і публікацій. Системний аспект інновацій випливає з сучасних концепцій техносфери як суспільного середовища, що розвивається як інфраіндустрія. Вона технологічно об'єднує не лише різні галузі діяльності, науку та виробництво товарів і послуг, але також і сферу побуту, складні технологічні системи людської діяльності та соціально-культурного життя [1].

Інноваційний розрив як диференціація країн був розглянутий у дослідженні [2] як модифікація культурного розриву. У якості основного у даному дослідженні є висновок про те, що сучасна культура носить техногенний характер. Це означає, що цінності сучасної людини та суспільства мають технологічну підоснову, відтак провідними є суспільства та системи їх цінностей, що задаються не традиційними, а високими тех- 
нологіями. Можемо частково погодитися з цим висновком, зокрема в частині впливу інновацій на зміни публічного управління, однак ми ні в якому разі не можемо відкидати вплив традицій.

Підтвердження такого підходу знаходимо у дослідженні [3], яке доводить, що традиційна культура є найважливішою умовою та передумовою інноваційного суспільного розвитку. Якщо традиція в момент свого зародження або традиція як факт культури певного періоду розглядається дослідниками як культурна інновація, то й традиційна культура “зміцнюється” або “слабшає” зі зміною соціокультурної ситуації в суспільстві, стаючи “двигуном” або “гальмом” інноваційної культури. При цьому присутній у суспільній свідомості й суспільній практиці традиціоналізм підсилюється, коли процеси модернізації приводять до істотного погіршення соціокультурного середовища. Відповідно максимальну ефективність трансформації можемо отримати у випадку максимального співпадіння векторів інновацій і традицій. На нашу думку, цей аспект можна розглянути як управлінське завдання.

Зазначені аспекти мають бути в основі управління, що грунтується на інституційному трикутнику [4, с. 30]. Він включає три взаємозалежних і пов'язаних між собою компоненти системи державного управління, що мають забезпечити ㄲï належне функціонування:

- інституції (установи, структури, організаціі);

- процеси (“правила гри”, норми, процедури);
- люди (кадри, державні службовці, виконавці, соціум).

Для впровадження будь-яких інновацій важлива інноваційна екосистема, що формує стули або перепони інноваціям. На основі інституційного підходу та відповідно до моделі “тропічного лісу" ("rainforest") [5] можемо розглянути їі у складі двох частин - “заліза” і “софту”, де під “залізом” розуміють створену фізичну інфраструктуру (економічний потенціал), під “софтом" - культуру, в якій формуються нові типи поведінки та соціальної взаємодії людей, що сприяють розвитку, зокрема й інноваційному. Одним 3 ключових процесів у створенні екосистеми є перехід від “ЕГОсистеми”, де вирішальну роль відіграє індивідуальний рівень, до “ЕКОсистеми”, коли всі рівні діють в рамках довірчих відносин.

Однак наразі в практиці публічного управління України зазначені аспекти міждисциплінарного підходу до розуміння бази інституційних трансформацій практично не знаходить практичного втілення в рамках реформ. Це призводить до втрати як їх інноваційного потенціалу, так і наявного соціального капіталу (психосоціальний потенціал за Е. Афоніним).

Таким чином, маловивченими залишаються питання методології розробки цілеспрямованих зміни інституціональної структури як детермінанти системної цілісності, вирішення проблеми оцінки взаємного впливу змін окремих економічних інститутів та аналізу динаміки всієї інституціональної структури.

Метою даного дослідження $€$ аналіз архетипних факторів функ- 
ціонування макросистем, на які потрібно звертати особливу увагу для пошуку найбільш ефективних точок докладання зусиль (ресурсів) в рамках застосування концепції інституційно-еволюційних траєкторій впровадження системних інновацій.

Методологія дослідження. Сучасна інноватика при вирішенні завдань публічного управління формується як міждисциплінарна область теорії і практики на стику психології, соціології, теорії управління, економіки та культурології. Ці підходи грунтуються на розумінні того факту, що один з найголовніших факторів пошуку, розробки та впровадження системних інновацій - це люди (соціум). Досить часто по новому інтерпретується формула 4P (marketing mix), й наразі вона розшифровується як "People, People, People \& People” [6].

Архетипний підхід узгоджується 3 підходом до управління системними змінами як природно-штучними системами [7]. Даний підхід також узгоджується й зі підходом до менеджменту знань. Відповідно до нього в контексті управління розвитком досить часто не враховується фактор так званих “неявних знань”, що включають навички (уміння) та культуру, властиві індивідам, але не усвідомлені ним. Один з відомих наукових афоризмів М. Полані, автора концепції “неявних знань”, "Ми можемо знати більше, аніж здатні розповісти” (англ. - We can know more than we can tell), ілюструє можливі джерела психосоціальних ресурсів інноваційного розвитку публічного управління.
Норт, проводячи паралелі між технологіями та інститутами, відзначав наявність високих витрат створення (start-up costs), ефектів навчання та координації, а також адаптивних очікувань [8-9]. Він також відзначав, що ключем до довгочасного росту є забезпечення не алокаційної, а адаптаційної ефективності, яку можливо забезпечити на основі психосоціальних ресурсів. Ефективні політико-економічні системи породжують гнучкі інституціональні структури, здатні подолати потрясіння та зміни, неминучі навіть при успішному розвитку. Відзначимо, що при формуванні таких систем має бути врахований фактор психосоціальних ресурсів розвитку, для чого незамінною є архетипна методологія.

Для цілей інституціонального планування, що передбачає передбачення, проектування, формування й контролю різних інститутів, що відображають цілісні властивості певної країни, ми пропонуємо використовувати концепцію інституційних стратегій розвитку [10-13], що має враховувати архетипну складову.

\section{Виклад основного матеріалу.} Управлінська наука кінця XIX - поч. XX ст. характеризувалася домінуванням неокласичного напрямку, що концентрує свою увагу на вивченні рівноважного стану економічних систем. Тому поступово стало виявлятися, що застосування неокласичної теорії дає адекватні результати тільки при аналізі інституційно-інваріантних економічних систем, розглянутих у короткостроковому періоді, але є ненадійним інструментом для аналізу транзитивних процесів, що характеризуються зміною ін- 
ституціональної структури соціуму. Цим пояснюється поява й розвиток інституціонального напряму.

В рамках нашого дослідження інноваційний розвиток доцільно розглянути як комбінацію інтелектуальних, ресурсних та інституціональних змін системи. Ці зміни створюють умови для нагромадження кумулятивного потенціалу, здатного освоювати новітні технології, створювати нові продукти, освоювати нові ринки, збільшуючи реальний продукт для споживання, забезпечуючи сприятливі умови для розвитку суспільства.

Ефективні інститути створюють такі стимули, які забезпечують економічний ріст. У цьому змісті інститути й відповідно інституціональні зміни можуть розглядатися через призму економії на трансакційних витратах, що, у свою чергу, є підставою використання порівняльних переваг у розвитку суспільного поділу праці, обміну, розширення виробничих можливостей та стійкого зростання.

Інноваційний процес як єдність ресурсно-технологічного й інституціонального аспектів відтворення, представляє інституціональну динаміку у формі взаємного впливу й відбору умов відтворення благ, а також соціальних умов для узгоджених дій.

В цьому контексті для більш точного розуміння сутності сучасних тенденцій та завдань публічного управління варто розглянути контекст інституційно-еволюційних траєкторій впровадження системних інновацій.

На основі дослідження [6] можемо виділити наступні ключові аспек- ти системних інновацій, що дають змогу визначити роль психосоціального потенціалу архетипів:

1) системні інновації - це нововведення, що впроваджуються в основу певної системи та впливають на 1ii цінності, культуру та пронизують усі їі підсистеми підштовхуючи їх до постійного розвитку та удосконалення;

2) системні інновацї - це удосконалення організаційних і бізнес-моделей, зміна моделей мислення та поведінки (якість мислення = якість продукту = якість життя);

3) системні інновації - це рішення, що базуються на роботі з системними властивостями та законами розвитку складних систем (ефект важеля, синергетичний ефект, закони гармонічного і сталого розвитку тощо);

4) системні інновації - це рішення, які виявляють приховані ресурси системи та активізують ї. внутрішній потенціал розвитку;

5) системні інновації - це рішення, що створюють сприятливі умови для інноваційної діяльності в системі (впровадження різних інновацій).

3 наведених дефініцій ми бачимо можливість й необхідність переходу від традиційних технократичних) підходів до системних змін до підходів, орієнтованих на створення нової бази сприяння трансформаціям на всіх рівнях, здатних як враховувати, так і впливати на звички та норми суспільства з метою підтримки ефективного та динамічного розвитку.

Зазначимо, що цей підхід не $є$ певною альтернативою існуючим. Наприклад, він відповідає ідеям pyxy Wellbeing Economy, експерти 
якого вважають, що важливі “зміни, які необхідні, жоден суб’єкт не може здійснити самостійно. Це вимагає співпраці та натхнення. А це означає підключення, організацію та посилення роботи організацій, груп та окремих осіб, які прагнуть побудувати економіку добробуту" [14].

Ці підходи знайшли своє втілення у 1990-х рр. в рамках інноваційних теорій сприяння високотехнологічним галузям і моделях соціокультурного сприяння інноваційному розвитку, що сформувалися на базі теорій економічного циклу та соціально-економічних концепцій розвитку й орієнтовані на практику. В цих теоріях роль інновацій як провідного фактора динаміки розвитку розглядається в наступних аспектах [15, с. 46-47], що безпосередньо стосуються нашого дослідження:

1) у розвитку інновацій значна роль інститутів; вони трактуються і як “гальмо” для нововведень, і як спосіб успішного вибору (за певних умов) між рішеннями-альтернативами;

2) у цілому визнається об'єктивна необхідність посилення ролі держави в управлінні розвитком (моніторинг, планування і прогнозування) у взаємодії з відповідними стейкхолдерами;

3) наявність практичних проблем інноваційної мотивації різних груп стейкхолдерів.

В якості прикладу двох інституційних підходів з діаметрально протилежним результатом та логікою системних реформ можемо розглянути КНР. Щоб пояснити причини сучасних економічних успіхів необхідно повернутися до 1978 р., коли країна перебувала в кризі (понад 300 млн осіб жили в абсолютній бідності) після експериментів зі створення народних комун і культурної революції.

Ден Сяопін зважився на ризикований, але продуманий експеримент з інституційної трансформації з метою створення ринкової економіки. Для цього був необхідний новий інструмент, який дозволив би розмовляти з народом на зрозумілій мові, i він вирішив звернутися до конфуціанства. “Щоб перейти ріку, потрібно намацати камені на дні”, - говорив Ден Сяопін, формуючи ідеологію політики “реформ і відкритості”. Якщо за Мао Цзедуна Конфуцій був “пацюком, що перебігає вулицю”, якого треба знищити, то Ден Сяопін використав конфуціанство як "ідеологічний ключик”, яким відкривалися серця простих китайців. Не відрікаючись від марксизму, китайський лідер звернувся до історичної пам'яті народу, тому що розумів, що конфуціанство протягом сотень років формувало менталітет китайця.

Фактично “геніальна інтуїція Ден Сяопіна виявилася співзвучною ідеям К. Юнга, який у результаті дослідження психіки людини дійшов висновку про те, що в структурі духовного світу людини крім особистісного несвідомого існує більш глибокий шар психіки - колективне несвідоме, що володіє загальною надособистою природою” [16, с. 87].

Необхідність формування аналогічних підходів до системних реформ обумовлена тим, що в Україні наразі незважаючи на масований дискурс цих питань, відбувається поглиблення негативних трендів, що 
формують загрози національній безпеці в стратегічній перспективі. На рисунку показана динаміка індексу реформ, що ілюструє їх “затухання” з 2015 р. (рисунок).

Водночас досвід країн, що свого часу здійснили "стрибки розвитку" показує, що вони були здійснені не на основі копіювання іноземного досвіду, а на створенні “органічних" моделей розвитку. Це в свою чергу формує значущість архетипної методології, що дає змогу визначити ті ідеї, що мають бути покладені в основу системних реформ.

Зокрема на основі аналітики В. Хіцяка [19], присвяченої аналізу відповідності народних практик українців економічним моделям сталого розвитку можемо зробити такі висновки, які можуть бути в основі системних економічних інновацій:

- менталітет українця як землероба відповідає тенденціям інноваційного забезпечення продовольчої безпеки, на основі чого доцільно планувати модернізацію цієї традиції і створювати умови для розвитку міської агрокультури (стимули для забудовників (теплиці на дахах), можливості для обміну продукцією (локальні ринки), навчання про нові агротехнології (вертикальні грядки, гідропоніка тощо));

- практики українців з використання продовольчих залишків для приготування органічних добрив або в якості їжі для тварин відповідає глобальним тенденціям екологізації економіки та продовження життєвого циклу продуктів;

- орієнтація українців на добробут дітей (для $32 \%$ українців це $є$ найважливішим чинником в житті) на протидію щастю “тут і тепер за будь-яку ціну” відповідає критерієм зрілості суспільства та моделі сталого розвитку. Ця особливість може бути основою інформаційних компаній щодо практик інноваційної політики та створення переваг сталого розвитку;

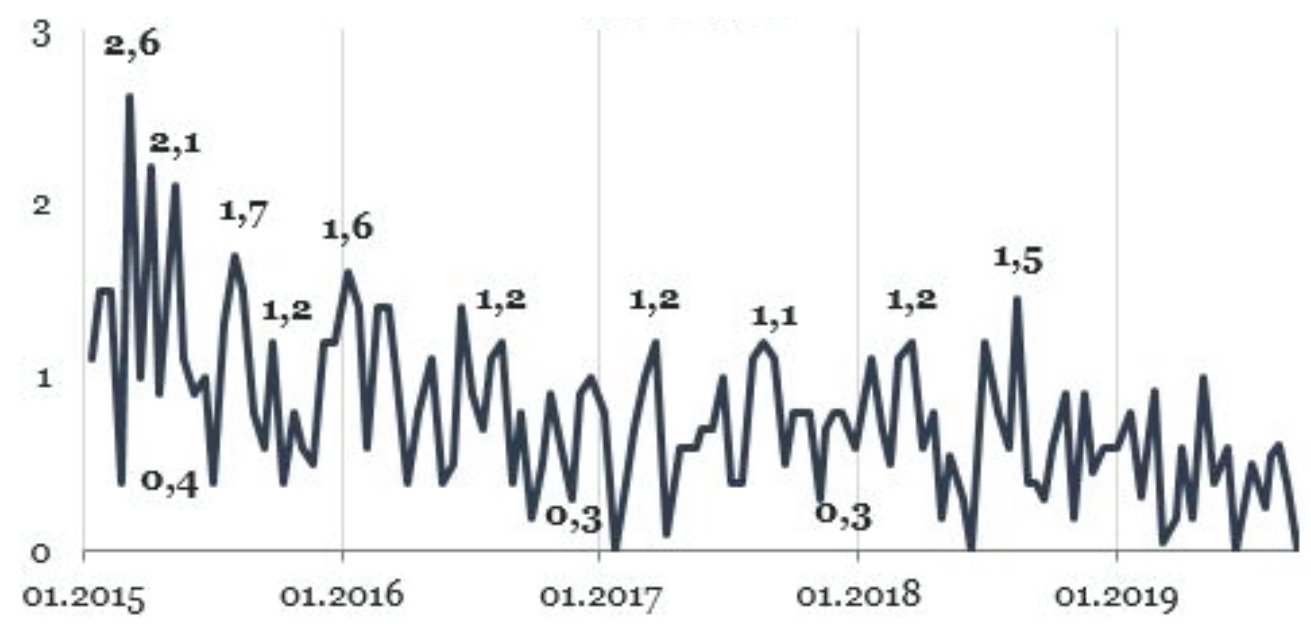

Індекс може приймати значення від -5 до +5 , значення вище +2 розглядаються як прийнятний темп реформ

Динаміка індексу моніторингу реформ [18] 
• зв’язок поколінь, емоційні зв'язки, передача традицій як риси культури українців набувають особливого значення в контексті сталого розвитку, зокрема при подоланні проблем нерівності та соціальної підтримки. Багато дослідників вважають, що уряд без залучення громадян не здатен впоратися з рядом завданням. В рамках визначення переваг архетипної методології варто відзначити, що зв'язок поколінь допомагає не лише краще бачити зміни, але й також визначати потреби інших груп суспільства;

- традиції з виробництва домашніх продуктів у “домашніх мануфактурах” можуть за мови сприятливого інституційного середовища в майбутньому стати основою буму малого інноваційного бізнесу;

- звичка українців зважати на те, “що люди скажуть” відповідає тенденціям зростання ролі локальних громад та формування “локально керованої децентралізованої циркулярної економіки”, основною ідеєю якої є розуміння кожним власної відповідальності в рамках практик сталого розвитку.

Таким чином, виходячи з логіки архетипної методології системні реформи будуть можливими у випадку:

1) наявності концепції системних трансформацій, яка включає чітке розуміння взаємозв'язків (змісту) суспільних функцій та змісту пропонованих системних інновацій. Можна використовувати досвід інших країн, однак накладаючи на архетипну матрицю та поточні реалії.

У даній концепції слід розуміти, які елементи ключові за потенцій- ним ефектом та конфліктним потенціалом, а які другорядні. Сьогодні ця робота не здійснюється з огляду на відсутність певних дієвих think thanks і механізмів впливу;

2) потрібно відслідковувати, доповнювати та реагувати на зміни. Запуск системних інновацій - це програма. Необхідні для i реалізації компетенції стосуються як здатностей швидкого і масштабного мислення, практичних навичок управління (включаючи аналітику, прийняття рішень, керівництво і т. д.), а також автономія в реалізації задуманого;

3) потрібно місце соціальної, управлінської та політичної взаємодії, 3 якої можливе здійснення системних проектів і програм.

Важливим аспектом розгляду інституційно-еволюційних змін є диференціація інститутів, залучених до процесів трансформації, а також різноманіття видів, форм організацій і процесів. Відзначимо, що раніше практично всі завдання виконувала мережа державних інститутів, 3 яких і формувалась “система”. Інститути громадянського суспільства становили незначні доповнення цієї системи. Більшість елементів системи і відносин між ними були доступні прямому управлінню. В сучасних умовах все більшу роль при формуванні змін відіграють ті елементи, які раніше розглядалися лише як доповнення, i ïx реальний вплив зростає. Сучасна інституційна рамка змін вже не є простою системою установ. Наразі ж суб'єкти й процеси в цій сфері є різнорідними, різноманітними, гетерохронними й підкоряються різній логіці, зокрема 
й архетипній. Роль і місце формальних установ стрімко зменшується, а відносини між різними елементами встановлюється ситуативно.

На основі вищевикладеного можна виділити певний набір об'єктивних критеріїв для аналізу якості інституційно-еволюційної траєкторії впровадження системних інновацій:

- прогрес в області сформованості ключових соціальних компетенцій;

- рівень досягнення результатів, необхідних для продовження впровадження системної інновації;

- синтез архетипів та комплексу рішень, що відображають суть системної інновації;

- відповідність змісту системної інновації вимогам часу;

- рівень і спрямованість системної інновації відповідно до суспільних запитів.

Висновки та перспективи подальших досліджень. У дослідженні розглянута архетипна методологія до визначення основ формування інституційно-еволюційних траєкторій впровадження системних інновацій. Результати дослідження доводять, що фактори успішності реформ як системних інновацій пов'язані не тільки зі змінами структур та функцій інституціонального механізму держави, а насамперед з соціальними чинниками. В дослідженні показано, що фактором успішності системних інновацій є створення унікального середовища змін на основі поєднання технологічно-інноваційного базису, економіки та соціально-культурної системи. Обгрунтовано, що для того, щоб ідеї та потенціал системних реформ перетворилися в реальні інновації, тобто реалізувалися в соціально-економічному просторі країни, необхідний цілий спектр об’єктивних і суб'єктивних причин, зокрема культурна “підтримка” інновацій відіграє досить важливу роль. Вважаємо, що в подальших дослідженнях необхідно конкретизувати вплив конкретних складових архетипів й траєкторії їх втілення в системних інноваціях.

\section{СПИСОК ВИКОРИСТАНИХ ДЖЕРЕЛ}

1. Демиденко Э. С. Ноосферное восхождение земной жизни: Монографический сборник статей по социально-экологической тематике. М.: "MAOP", 2003. 247 с. URL: http://www.kaliningrad.wie.su/ WiE-en/noosfernoe_voskhozhdenie zemnoj_zhizni.pdf (дата звернення: 12.11.2019).

2. Шугуров, М. В. Международное право и технологический разрыв: проблемы и решения. Право и политика: веб-сайт. 2011. № 5 (137). URL: http://www.nbpublish.com/ library_read_article.php?id=-14616 (дата звернення: 12.11.2019).

3. Сараф М. Я. Цивилизационная инвариантность проблемы традиционализма и новаторства. РАН. ИНИОН. Отд. науч. сотрудничества и междунар. связей; отв. ред. Ю. С. Пивоваров. М., 2013. Ч. 2.

4. Зарубіжний досвід державного управління: доцільність і можливості застосування в Україні : наук. розробка / авт. кол.: І. А. Грицяк, Л. А. Шереметьєва, К. К. Баранцева та ін. К. : НАДУ, 2012.56 с.

5. Хван В., Хоровитт Г. Тропический лес. Секрет создания следующей Силиконовой долины; пер. с англ. под ред. А.Ф. Уварова. Томск: Издво Томск. гос. ун-та систем упр. и радиоэлектроники. 2012. 332 с. 
6. Жалевич А. Что такое системные инновации?: веб-сайт URL: http:// zhalevich.com/myschlenie/85systems/403-sistemnye-innovacii. html (дата звернення: 12.11.2019).

7. Вадалажская Т. Почему “системная реформа образования” невозможна: веб-сайт. URL: http://fly-uni.org/ blogi/pochemu-sistemnaja-reformaobrazovanija-nevozmozhna/ (дата звернення: 12.11.2019).

8. Норт Д. Институты, институциональные изменения и функционирование экономики. М., 1997.

9. North D. Institutions and Economic Growth: An Historical Introduction. World Development. 1989, vol. 17, no. 9. pp. 1319-1332.

10. National Security \& Innovation Activities: Methodology, Policy and Practice. edited by Dr. of Economics, Prof. O. Prokopenko, Ph.D in Economics V. Omelyanenko, Ph.D in Technical Sciences, Assoc. Prof. Yu. Ossik. Ruda Śląska: Drukarnia i Studio Graficzne Omnidium. 2018. 416 p.

11. Omelyanenko V. A. Archetypical analysis of the innovation development resources of European public administrative space (comparative approach). Public management. 2018. № 4 (14). pp. 198-212.

12. Стратегічне управління системною стійкістю національної інноваційної системи: колективна монографія. Суми: Триторія, 2019. 222 с.

13. Omelyanenko V., Semenets-Orlova I., Khomeriki O., Lyasota L., Medviedieva Yu. Technology transfer management culture (education-based approach). Problems and Perspectives in Management. 2018. № 16 (3). C. 454-463. http://dx.doi.org/10.21511/ppm.16 (3).2018.36

14. Wellbeingeconomy: веб-сайт. URL: https://wellbeingeconomy.org/howwill-we-change-the-system (дата звернення: 12.11.2019).
15. Богатова Е. В. Инновации как фактор экономической динамики в теориях цикла и социально-экономических концепціях. Известия РГПУ им. А. И. Герцена. 2009. № 103. С. 41-47.

16. Просеков С. А. Менталитет китайцев и реформы Дэн Сяопина. Философские науки. 2015. № (1). C. 86-98.

17. Лысенко В. Почему китайские реформы должны стать примером для Украины? Українська правда: веб-сайт. 2018. URL: https://www.pravda.com.ua/rus/ columns/2018/09/5/7191096/ (дата звернення: 12.11.2019).

18. Динаміка індексу моніторингу peформ: веб-сайт. URL: http:// imorevox.org/pелизы-pdf/ (дата звернення: 12.11.2019).

19. Хіцяк В. Шість звичок українців, які несподівано сприяють сталому розвитку. НВ Бізнес: веб-сайт. 3 листопада 2019. URL: https://nv.ua/ukr/ biz/experts/gorodi-i-konservaciyashist-zvichok-ukrajinciv-yakinespodivano-spriyayut-stalomurozvitku-tochka-zoru-50051306. h t m l ? f b c li d = I w A R 2 J C cvzFAavWRtxFVItciB MexY LOUV5 6yN5-NCBUsbkxW2Fl61IR8Y (дата звернення: 12.11.2019).

20. Кац И. С. Эволюция институциональных инноваций в общественном секторе. Журнал экономической теории. 2018. Т. 15. № 2. С. 291-308. References

1. Demydenko, E. S. (2003). Noosfernoe voskhozhdenie zemnoi zhizni [Noospheric Ascent of Earthly Life]. Moscow: "MAOP". Retrieved from http://www.kaliningrad.wie.su/WiEen/noosfernoe_voskhozhdenie_zemnoj_zhizni.pdf [in Russian].

2. Shugurov, M. V. (2011). Mezhdunarodnoe pravo i tekhnologicheskii razryv: problemy i resheniia [International law and the technological 
gap: problems and solutions]. Pravo i politika - Law and Policy, 5 (137). Retrieved from http://www.nbpublish.com/library_read_article. php?id=-14616 [in Russian].

3. Saraf, M. Ia. (2013). Tcivilizatcionnaia invariantnost problemy traditcionalizma i novatorstva [Civilizational invariance of the problem of traditionalism and innovation]. RAS. INION. [in Russian].

4. Hrytsiak, I. A. et al (2012). Zarubizhnyi dosvid derzhavnoho upravlinnia: dotsilnist i mozhlyvosti zastosuvannia $\mathrm{v}$ Ukraini [Foreign experience of public administration: expediency and possibilities of application in Ukraine]. Kyiv: NASA. [in Ukrainian].

5. Khvan V., Khorovitt G. (2012). Tropicheskii les. Sekret sozdaniia sleduiushchei Silikonovoi doliny [A tropical forest. The secret to creating the next Silicon Valley]. Tomsk: Izdatelstvo Tomsk. gos. un-ta sistem upr. i radioelektroniki [in Russian].

6. Zhalevich A. Chto takoe sistemnye innovatcii? [What is system innovation?]. zhalevich.com. Retrieved from http://zhalevich.com/ myschlenie/85-systems/403-sistemnye-innovacii.html [in Russian].

7. Vadalazhskaia T. Pochemu "sistemnaia reforma obrazovaniia” nevozmozhna [Why "systemic education reform" is impossible]. fly-uni.org. Retrieved from http://fly-uni.org/blogi/pochemu-sistemnaja-reforma-obrazovanijanevozmozhna/ [in Russian].

8. North, D. (1997). Instituty, institutcionalnye izmeneniia i funktcionirovanie ekonomiki [Institutions, institutional changes and the functioning of the economy]. Moscow. [in Russian].

9. North, D. (1989). Institutions and Economic Growth: An Historical Introduction. World Development, 17(9), 1319-1332.
10. Prokopenko, O., Omelyanenko, V., Ossik, Yu. (2018). National Security \& Innovation Activities: Methodology, Policy and Practice. Ruda Śląska: Drukarnia i Studio Graficzne Omnidium.

11. Omelyanenko, V. A. (2018). Archetypical analysis of the innovation development resources of European public administrative space (comparative approach). Public management, 4 (14), 198-212.

12. Stratehichne upravlinnia systemnoiu stiikistiu natsionalnoi innovatsiinoi systemy [Strategic management of the systemic sustainability of the national innovation system]. Sumy: Trytoriia, 2019. [in Ukrainian].

13. Omelyanenko, V., Semenets-Orlova, I., Khomeriki, O., Lyasota, L., Medviedieva, Yu. (2018). Technology transfer management culture (education-based approach). Problems and Perspectives in Management, 16 (3), 454-463. http://dx.doi. org/10.21511/ppm.16(3).2018.36

14. Wellbeingeconomy. wellbeingeconomy.org. Retrieved from https:// wellbeingeconomy.org/how-will-wechange-the-system.

15. Bogatova E. V. (2009). Innovatcii kak faktor ekonomicheskoi dinamiki v teoriiakh tcikla i sotcialno-ekonomicheskikh kontceptciiakh [Innovation as a factor in economic dynamics in cycle theories and socio-economic concepts]. Izvestiia RGPU im. A.I. Gertcena - Proceedings of the Russian State Pedagogical University named after A.I. Herzen, 103, 41-47. [in Russian].

16. Prosekov, S. A. (2015). Mentalitet kitaitcev i reformy Den Siaopina [The Chinese mentality and reforms of Deng Xiaoping]. Filosofskie nauki Philosophical Sciences, 1, 86-98. [in Russian].

17. Lysenko V. (2018). Pochemu kitaiskie reformy dolzhny stat primerom dlia 
Ukrainy? [Why should Chinese reforms be an example for Ukraine?]. pravda.com.ua. Retrieved from https://www.pravda.com.ua/rus/ columns/2018/09/5/7191096/ [in Ukrainian].

18. Dynamika indeksu monitorynhu reform [Dynamics of the reform monitoring index]. imorevox.org. Retrieved from http://imorevox.org/ релизы-pdf/ [in Ukrainian].

19. Khitsiak V. (2019). Shist zvychok ukraintsiv, yaki nespodivano spryiaiut stalomu rozvytku [Six habits of ukrainians that suddenly contribute to sustainable development]. nv.ua.
Retrieved from: https://nv.ua/ukr/ biz/experts/gorodi-i-konservaciya-shist-zvichok-ukrajinciv-yakinespodivano-spriyayut-stalomurozvitku-tochka-zoru-50051306. html? fbclid=Iw A R 2 J C - c vzFA a v W R t x F V Itci B M ex Y LOUV5_6yN5-NCBUsbkxW2Fl61IR8Y [in Ukrainian].

20. Katc, I. S. (2018). Evoliutciia institutcionalnykh innovatcii v obshchestvennom sektore [The evolution of institutional innovations in public sector]. Zhurnal ekonomicheskoi teorii - Journal of Economic Theory, 15(2), 291-308. [in Russian]. 